\title{
The relative taxonomic value of morphological characters in the genus Nummulites (Foraminiferida)
}

\author{
ANDREW RACEY \\ Geochem Group Limited, \\ Chester Street, \\ Saltney, \\ Chester, $\mathrm{CH} 4$ 8RD
}

\begin{abstract}
The main evolutionary trends in the nummulites are briefly summarised and the value of certain morphological characters in species discrimination are summarised. The degree of interdependence of each morphological character on all other characters is assessed and the characters are weighted in order of importance. Environmental and ontogenetic effects on each character are then reviewed and the characters reweighted in order of importance. J. Micropalaeontol., 11 (2): 197-209, December 1992.
\end{abstract}

\section{INTRODUCTION}

The main objectives of this paper are to assess the relative importance of the different taxonomic characters in the genus Nummulites (and related forms) and to summarise the ways in which environment may affect morphology in the Foraminifera, paying particular attention to the larger Foraminifera. The work comprises a review of published information, concentrating mainly on the family Nummulitidae, together with the authors own observations on the Late Palaeocene to Early Miocene nummulitid fauna of Oman. Of the seven principal nummulitid genera only Operculina, Heterostegina and Cycloclypeus have extant descendants, Nummulites having become extinct in the early Oligocene, Assilina in the late Middle Eocene, Ranikothalia in the Late Palaeocene and Spiroclypeus in the early Miocene.

\section{GLOSSARY OF TERMS}

Septal filament.: Extension of a septum over the lateral surface of the test between the spiral laminae.

Septal trace: The surface expression of septum on the outer surface of the test.

Septum : Partitions separating the chambers in each whorl. Trabeculae : Narrow unperforated strip on the lateral wall of the chamber which represents the surface expression of the sutural canals which extend forwards and backwards from the septum.

Alar Prolongation : A lateral extension of the chamber cavity over the surface of the test.

Marginal Cord : A complex three-dimension meshwork of canals encased in shell material, but open to the outside, which forms the keel of the test and assumes the function of the aperture seen in other genera of foraminifera.

Tripartition : A threefold division of the spire into three distinctive styles of coiling usually "tight" in the early whorls, "loose" in the middle whorls, then "tight" again in the outer whorls.

\section{MORPHOLOGY}

Nummulitids are characterised by a flat planispiral coil which is bilaterally symmetrical about the equatorial plane. They all possess a marginal cord with an internal canal system, and numerous equatorial chambers which may be simple (Nummulites, Assilina, Ranikothalia and Operculina) or divided into chamberlets (Heterostegina, Spiroclypeus, Cycloclypeus). Lateral chamberlets are present in Spiroclypeus, whilst annular chambers characterise Cycloclypeus. Genera with simple chambers are distinguished on the basis of the involuteness/ evoluteness (presence/absence of alar prolongations) of the test, the rate of opening of the spire, the shape of the chambers, the presence/absence of trabeculae and the presence/absence of a coarse canaliculate marginal cord.

Morphological "gradation" has been observed between some of the these genera e.g. Operculina and Heterostegina (Papp and Kupper, 1954) and Heterostegina and Cycloclypeus (Tan Sin Hok, 1932) and is discussed at length by these authors and Racey (1988). However, for the purposes of this study it is suffice to note that the development / non-development of alar prolongations can occur without the introduction or loss of any of the small number of structural elements which makeup a nummulitid test, the difference between the genera being relatively "simple" e.g. the presence of annular chambers in a nummulitid implies that such a species belongs to the genus Cycloclypeus whilst lateral chambers indicate that a species belongs to the genus Spiroclypeus.

The morphology of Nummulites is illustrated in Fig. 1. The test shape varies from flat to subglobular, the periphery being sharp to rounded or somewhat undulose. The point most distant from the equatorial plane is described as polar. The test is composed of planispirally coiled chambers, separated by septa. Successive whorls are bounded by a spiral sheet which incorporates the peripheral marginal cord. In axial section, the chambers appear as chevron-shaped cavities separated by successive turns of the spiral sheet. The tapering lateral extensions of these cavities are known as alar prolongations. The initial chamber (proloculus) is spherical, 
whilst the second chamber (deuteroconch) is generally kidney shaped, the following chambers may be higher than long, longer than high, or isometric. The spire may be lax (few whorls in a given radius) or tight (many whorls in a given radius). Septal filaments, formed by the extension of the septa over the lateral surfaces of the test between successive spiral sheets, are often visible on the test surface and in oblique thin sections. These may be radial, sigmoidal, meandrine or may branch to form a reticulum. The pattern of pillars/granules is often species diagnostic; they may be arranged on and/or between the septal filaments or over the poles to form polar plugs/pillars. In well-preserved specimens fine perforations can be seen over most of the test; only the septal filaments, septa, marginal cord and pillars are largely imperforate. Nummulites possess a canaliculate marginal cord (Fig. 1). Röttger (1984), in a study of the Recent nummulitid Heterostegina depressa, demonstrated the importance of this canal system for growth, locomotion, reproduction, excretion and protection. Hottinger (1977a) noted that the nummulitids, unlike most multilocular Foraminifera, rarely have true primary or secondary apertures, a conclusion supported by Rottger (1984). Instead, the canal system replaces the primary aperture seen in most other Foraminifera and allows communication between the chamber cavities and the lateral surfaces of the test.

\section{EVOLUTIONARY TRENDS WITHIN THE NUMMULITES: CHANGE IN MORPHOLOGY WITH TIME}

\section{GENERAL}

Before considering the relative importance of the different morphological characters in nummulite identification it is necessary to identify which evolutionary changes in morphology are currently used in phylogenetic studies.

Hottinger (1981) concluded that larger foraminiferal lineages could only be used to study evolution when :-

(1) Evolutionary trends are unidirectional with time, e.g. the gradual increase in test size of B-Forms and proloculus size in A-forms found within lineages of Nummulites.

(2) Trends can be interpreted as being genetically controlled. For example, broken tests of Nummulites and living nummulitids such as Operculina often regenerate shell material in the damaged area until the original test proportions are reached, i.e. test size/shape are genetically "fixed" timedependant characters.

(3) Trends can be explained as having a positive selectional value in terms of functional morphology. The trend towards larger flatter test in Nummulites, for example, increases the surface area to volume ratio of the test, thus benefitting the algal symbionts, and may be regarded as an adaptation to oligotrophic or low light level conditions.

The most striking feature in the evolution of Nummulites is the increase in test size from their initial radiation in the Late Palaeocene to the major extinction of most really large species at the Middle-Upper Eocene boundary. This extinction coincides with the rapid decrease in numbers of many spinose planktonic foraminifera such as Acarinina, Morozovella and Truncorotaloides (Keller, 1983), and may possibly be related to the decrease in oceanic temperature noted by stable isotope workers (e.g. Shackleton \& Kennet 1975). Few species of Nummulites survive into the Upper Eocene, and Nummulites finally became extinct in the mid-Oligocene. Evolution, from generally highly diversified assemblages of smaller forms in the Lower Eocene to less diverse assemblages of specialized large forms in the Middle Eocene is one of the most striking features in this genus.

All Nummulites have a characteristic set of generic characters which are broadly divided into two groups :-

(1) Those which do not change in form or function with time, e.g. the presence of a marginal cord and undivided planispirally arranged chambers.

(2) A set of characters which vary with time and which therefore have a biostratigraphic significance e.g. the increase in test diameter of B-Forms and proloculus diameter of AForms. Such quantitative characters are often of taxonomic value, and may change at different rates from one lineage to another (Schaub, 1981).

\section{EVOLUTIONARY TRENDS IN NUMMULITES}

(a) Test Size

(i) The overall size of B-forms increases with time in most lineages. Size increases in the A-generation are, however, less marked, and this leads to a progressive accentuation of dimorphism with time (Schaub, 1963, 1981; Blondeau, 1972; Herb \& Heckel, 1973). Nummulites originated in the Late Palaeocene when they were represented by small species $(<6 \mathrm{~mm}$ in diameter), and reached their acme of development in the Middle Eocene, when they attained their maximum size. For example, Nummulites millecaput Boubée reached up to $160 \mathrm{~mm}$ in diameter (Bieda, 1963, p. 191). The overall trend within many of these lineages in the Middle Eocene was towards larger and flatter tests, usually with a greater number of whorls.

This increase in size was accomplished, at least in part, by the introduction of intercalary whorls which produced multiple spires. In Oman this is commonly observed in Middle Eocene species such as Nummulites perforatus, $N$. maculatus, $N$. somaliensis, and N. gizehensis. Tripartition of the spire in Nummulites is often associated with the introduction of intercalary whorls and is best developed in species with thicker tests, such as those of the N. perforatus lineage. In some tripartite species the test walls of the outermost whorls are thinner and the marginal cord is lost, e.g. in N. obtusus (Racey, 1988, pl. 5.5, fig. 10) and N. perforatus (Racey, 1988, pl. 5.5, fig 3). Such thinning is usually accomplished by splitting of the spiral sheet and is best-developed in the most distal walls on either side of the equatorial plane. In N. maculatus, N. gizehensis and $N$. somaliensis the whorl laminae thin markedly away from the marginal cord towards the poles in axial section (Racey, 1988, pl. 5.4, fig. 17; pl. 5.5, fig. 21), forming a series of narrow, elongated, rectangular cavities between these thin walls. Samanta (1981b) suggests that such cavities in N. maculatus could have housed algal symbionts, as suggested by Haynes 


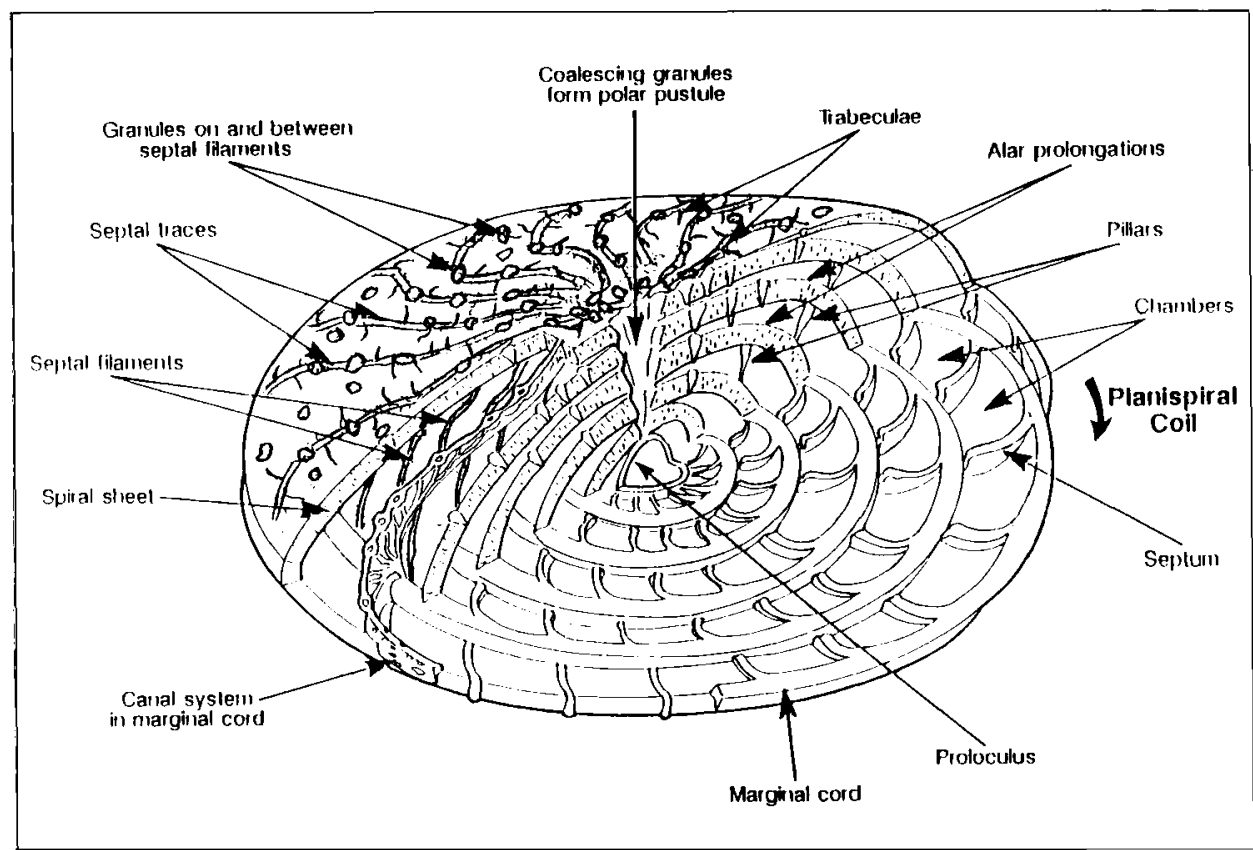

Fig. 1. Test structure of Nummulites, megalospheric form (modified from Carpenter 1850, Golev 1961 and Barrett 1974)

(1965) for other members of the Rotalidae. In large B-Forms such as N. maculatus and N. gizehensis the spiral laminae on each side of the test are modified to form long narrow, elongated cavities separated by thin walls (Racey, 1988, pl. 5.4, fig. 17; pl. 5.3, fig. 4). Such modifications also produce flatter tests. These "lateral chamberlets" are similar to those noted in Lepidocyclina which have been interpreted as "algal culture vessels" (Lee et al. 1979).

If the development of large complex tests was related to an increased need for algal symbionts, then the end-Middle Eocene extinction may have been due to the extinction of such symbionts (Samanta, 1981b). If large species were so highly specialized that most of their energy requirements had to be obtained through algal symbiosis, possibly under oligotrophic conditions (Hallock, 1985), they would have been poorly adapted to survive the extinction of their symbionts.

(ii) The increase in test size of A-Forms with time is much less marked, with test diameters rarely exceeding $8 \mathrm{~mm}$. The introduction of intercalary whorls is very rare and has not been noted in any of the Omani material. The author knows of only a single published record of intercalary whorls in an AForm (N. millecaput figured by Bieda (1963; pl. 10, fig. 1). However, Bieda's plate shows no obvious thinning of the spiral laminae with the introduction of the intercalary whorl, nor does it show the complex meandriform septal filaments which are common in the B-Form.

\section{(b) Proloculus Size in A-Forms}

Many authors (e.g. Schaub, 1963, 1981; Blondeau, 1972 and Samanta, 1981a) have stated that one of the most noticeable evolutionary trends in Nummulites is the increase in proloculus size with time. Proloculus diameters increase from approximately $0.1 \mathrm{~mm}$ in the Upper Palaeocene to a maximum of about $1 \mathrm{~mm}$ in the later part of the Middle Eocene, i.e. when the BForms reach their maximum test diameters. Dimorphism is therefore most marked in late Middle Eocene species making it difficult to pair A- and B-forms of the same species. Such trends only hold for species within a single lineage. Large proloculus sizes $(>0.5 \mathrm{~mm}$ in diameter) are, however, mostly restricted to Middle Eocene species. However, small proloculus sizes do not necessarily indicate the presence of primitive (older) species as was observed within the Seeb Limestone at Wadi Rusayl, Oman where unreworked, very small "primitive" Nummulites minutus (test diameter $=0.85-1.30 \mathrm{~mm}$; proloculus diameter $=0.075-0.090 \mathrm{~mm}$, see Racey 1988 and 1992 for description) were found with the larger, "more evolved" Middle Eocene species $N$. obesus (test diameter $=$ $3.77-6.43 \mathrm{~mm}$; proloculus diameter $=0.36-0.80 \mathrm{~mm}$ ). If, however, only N. minutus nov. sp. were present, the sample would probably have been dated as Upper Palaeocene on the basis of test and proloculus size.

Hottinger (1977b) has suggested that proloculus size increases with time because it reflects the volume of a young specimen's protoplasm. This in turn affects the size of its pseudopods and therefore determines the growth rate (Hottinger, 1977b, fig. 23). The largest proloculus sizes are therefore almost invariably found in species which have large B-Forms. However, Hallock (1985) has demonstrated that for such semiperalous organisms with life spans limited to one year, e.g. Recent Amphistegina, the disadvantages of reduced fecundity outweigh the advantages of slightly increased embryon sizes. Consequently only very large megalospheres are advantageous. This may explain why an increase in proloculus size is not consistently observed in all larger foraminiferal lineages.

\section{(c) Septal Filaments}

Septal filaments show an increase in complexity with time and can broadly be divided into three groups; simple, meandriform and reticulate. Simple radiating (striate), falciform, or curved septal filaments predominate in Upper Palaeocene to Lower Eocene species (though they are also present in later species); meandriform and complex branching septal filaments are most common in Middle Eocene species and reticulate septal filaments are common in the Upper Eocene N. fabianii and attain their acme of development in the Oligocene $N$. fichteli group.

\section{(d) Ornament (pillars and granules)}

Schaub (1981) suggests that within certain lineages the amount of ornamentation increases with time, for example, in the $N$. 


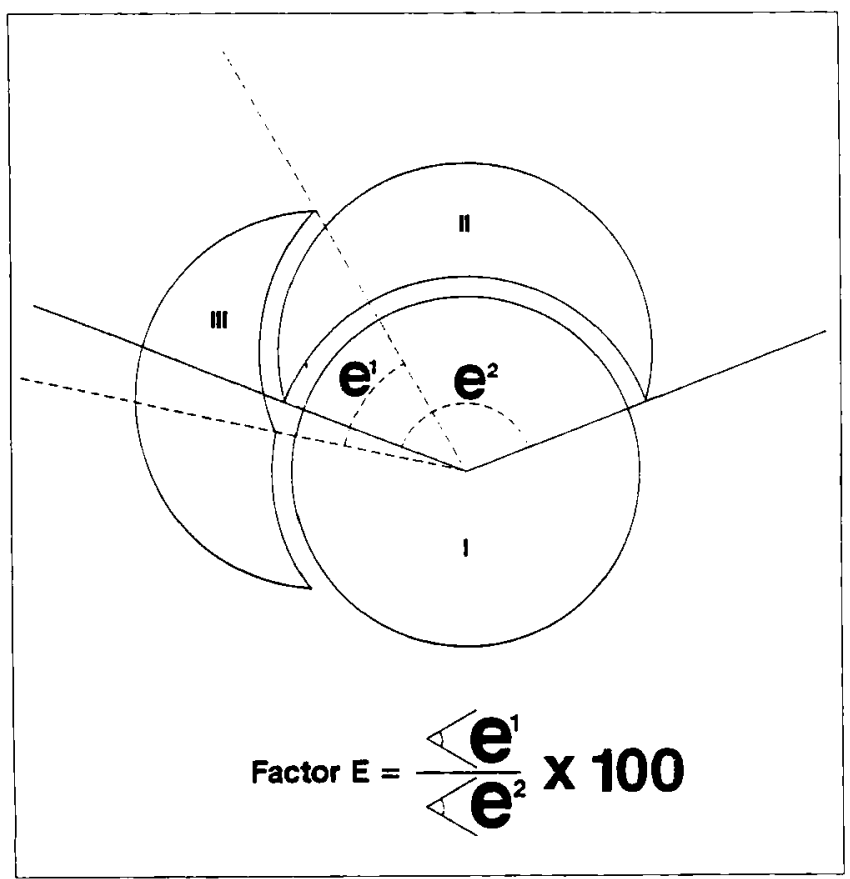

Fig. 2. Method of calculation of Factor E (after Van der Vlerk \& Bannink 1969)

burdigalensis and N. partschi groups. However, although early species within these two groups have few pillars, younger species often exhibit a wide range of variation in ornament within single assemblages.

\section{(e) Embryonic Chambers}

Various biometric methods for studying the embryonic development of larger foraminifera have been proposed of which one, the Factor E method of Van der Vlerk \& Bannink (1969) is herein applied for the first time to Nummulites (see Fig. 2 for method of calculation). Van der Vlerk \& Bannink (1969) tried to determine the age of Operculina - bearing rocks by measuring the degree of enclosure of the second chamber by the third and quantifying this as "Factor E". They studied a number of Eocene to Recent species of Operculina from Indonesia and noted a marked increase in the value of Factor $E$ with time. However, they did not mention which species were measured and it is unlikely that the specimens studied were from the same lineage, though this is known to be important. Whittaker \& Hodgkinson (1979) tested this method using Operculina ammonoides and O. bartschi from the Togopi Formation (Pliocene to Pleistocene), Sabah, Malaysia. They demonstrated that $O$. ammonoides yielded Factor $E$ values indicative of an Late Pliocene age, whilst $O$. bartschi gave an Early Miocene age. They also examined Operculina heberti from the Palaeocene of France which gave an "Oligocene" date; Operculinella from the Middle Miocene gave a fairly accurate result whilst Recent Operculina ammonoides gavevalues slightly higher than those of Van der Vlerk \& Bannink's Recent species. The species studied did not, however, belong to the same lineage.

In the writer's opinion, the value of Factor $\mathrm{E}$ as an indicator of age has not yet been assessed properly, since none of the studies mentioned above involved successive species from well-known and well-dated lineages. However, any change in Factor $E$ with time, should be more easily recognisable, and therefore of greater stratigraphic value, if measured within a single lineage, since such changes would, theoretically at least, be more uniform. Recent work on the genus Nummulites, especially that of Schaub (1981), has led to a better understanding of nummulite phylogeny and to the improved definition and dating of several nummulite lineages. Consequently, it was decided to test the Factor E hypothesis by using two well-known nummulite lineages ( $N$. fichteli and N. perforatus) from Oman. Additional data were obtained by measuring some of Schaub's (1981) figures and plates in order to give a broader data-base and wider geographical coverage. Trends in Factor $E$ values are notably different for these two lineages and the results are outlined briefly below:-

\section{N. fichteli lineage}

(i) N. ptukhiani from the Upper Lutetian. Factor $\mathrm{E}=16.42$ 25.76. Mean $=18.4$. Nine measured specimens.

(ii) N. fabianii from the Upper Eocene. Factor $E=17.21-28.3 .3$ Mean=23.22. Fifteen measured specimens.

(iii)N. fichteli from the Lower Oligocene. Factor $\mathrm{E}=31.06-42.31$. Mean=37.14. Fifteen measured specimens.

\section{N. perforatus lineage}

(i) N. campesinus from the Upper Ypresian. Factor $\mathrm{E}=17$ 29.61. Mean $=22.69$. Ten measured specimens.

(ii) $N$. obesus from the Lower Lutetian. Factor $\mathrm{E}=24.47-48.75$. Mean=36.34. Fifteen measured specimens.

(iii) N. beneharnensis from the lower part of the Middle Lutetian. Factor $E=10.7-23.8$. Mean=22.6. Eight measured specimens. (iv) N. deshayesi from the upper part of the Middle Lutetian to Upper Lutetian. Factor E=18.17-37.12. Mean=31. Eight measured specimens.

(v) N. perforatus from the Upper Lutetian. Factor E=27.6641.71. Mean $=33.71$. Fifteen measured specimens.

The $N$. fichteli lineage showed an increase in Factor $\mathrm{E}$ from 18.4 for Biarritzian species (N. ptukhiani), to 23.2 for the Upper Eocene $N$. fabianii to 37.4 for $N$. fichteli in the Lower Oligocene. However, the N. perforatus lineage showed an initial increase from 22.7 for Upper Ypresian-basal Lutetian N. campesinus to 36.3 for basal to Lower Lutetian N. obesus. Thereafter values for Middle and Upper Lutetian forms show a slight drop for N. beneharnensis (22.6), and followed by an increase from 31-34 for $N$. deshayesi and N. perforatus.

Although Factor $\mathrm{E}$ for Nummulites has not been used previously to date sequences it seems to show distinctchanges within individual nummulite lineages. However, the nummulite lineages studied above did not show the same trend, and at present it is not possible to suggest why this should be the case.

\section{Mechanism of Evolutionary Change}

The geographic dispersal of a new species is usually too rapid for detection with the resolution currently provided by the biostratigraphic time scale. The limitation of this resolving power may explain why punctuated evolution appears within a lineage showing continuous, gradual changes. Within 
the nummulitids phyletic gradualism predominates, whilst "punctuations" may be due to imperfections of the geological record. The gradualistic trends are often due to gradual modifications of existing characters such as the increase in test size of B-Forms and proloculus size of A-Forms in successive species of the N. perforatus lineage. Punctuations occur at the beginning of lineages and are due to the introduction of characters which show no gradation between ancestor and descendant, i.e. the species does or does not have a new character.

For the genus Nummulites the principal evolutionary changes are therefore an increase in test size of B-forms, (with an associated increase in the number of whorls) an increase in proloculus size of A-forms and an increase in complexity of septal filaments in both A \& B forms. In general it has been these gradual changes that have been used to subdivide the genus.

\section{RELATIVE TAXONOMIC VALUE OF MORPHOLOGICAL CHARACTERS}

Gradual morphological changes have often been used to delineate evolutionary lineages within the genus Nummulites, and have enabled workers to recognise more nominal species than in any other larger foraminiferal genus. This has occurred because authors have failed to assess the relative values of characters used to distinguish species. Neither Blondeau (1972) nor Schaub (1981) in their monographic works on Nummulites (and Assilina) sought to rank characters in order of taxonomic importance, possibly because they did not think it necessary but more probably because morphological characters used for species discrimination are to some extent interdependent, and most characters may be influenced by environmental factors.

\section{INTERDEPENDENCE OF MORPHOLOGICAL CHARACTERS}

It has become apparent to the writer that many characters (e.g. spire regularity and chamber shape) mentioned in species descriptions are to a greater or lesser extent interdependent. This fact may possibly be generally understood, but is usually ignored. It is also known, for example, that test size is influenced by environmental factors such as temperature, water depth and substrate (see below). The principal characters used for species discrimination in Nummulites are weighted (Fig. 3) in order of taxonomic importance according to the degree of interdependence. The taxonomic value of a character is thought to be inversely proportional to the number of characters affecting its development. Test shape, being influenced by six other factors, is thus considered less important than regularity of spiral growth which is affected by only two. The presence or absence of characters such as pillars and granules, tripartition and doubling of the spire, are recorded and are especially valuable because they are not present in all species. If environmental influences are set aside, the morphological characters of specific value can be arranged in the following theoretical order of importance:-

(1) Proloculus size and proloculus shape in the megalospheric generation.
(2) Marginal cord and canal system, trabeculae.

(3) Regularity/irregularity of spire, tripartition of spire, pillars/granules.

(4) Alar prolongations, septa, chambers, tightness/looseness of spire.

(5) Septal filaments/traces, doubling of spire, reversals.

(6) Test shape.

(7) Test size.

The environmental and genetic factors affecting this ranking are outlined below and briefly summarised in Fig. 4, and in the light of these considerations, the characters are reweighted.

\section{ENVIRONMENTAL AND ONTOGENETIC EFFECTS ON MORPHOLOGICAL CHARACTERS}

\section{(1) Test Size}

Ross $(1972,1975)$ has observed that Marginopora vertebralis on the Great Barrier Reef reaches reproductive maturity after about two years in shallow water $(8-10 \mathrm{~m})$, where it attains diameters of $13-15 \mathrm{~mm}$. In deeper water $(25-30 \mathrm{~m})$ it grows more slowly, reaching a larger size $(22 \mathrm{~mm})$ before reproduction, suggesting a less optimal environment. Consequently, it may be concluded that for this larger foraminifer test size is related to water depth and temperature. Reiss \& Hottinger (1984) have noted that Heterostegina depressa and Operculina ammonoides in the Red Sea (see (2) below) vary in shape but not in size with increasing water depth. Water temperature within the depth range of these foraminifera was observed to be relatively constant in the area studied. Their results suggest that the variation observed in the test shape of these two species is unlikely to be temperature controlled. Hallock \& Glenn (1986) noted that under favourableconditions, larger foraminifera mature rapidly and reproduce at relatively small adult sizes, whereas under unfavourable conditions (low light, low temperature) they grow more slowly thus maturing and reproducing at larger sizes. This phenomenon was also observed by Bradshaw (1957) in his study of the smaller benthic species Streblus beccarii tepida. Hallock \& Glenn (1986) also conclude that if conditions are marginal for growth, but outside the range of tolerance for reproduction, growth continues until giant individuals are produced. This often occurs when living shallow-dwelling $(<20 \mathrm{~m})$ individuals are washed into deeper (50-100m) environments (Ross, 1972; Hallock, 1986).

Changes in substrate, often related to changes in water depth, have also been thought to cause variation in the size of fossil forms. Pomerol (1961) noted that the size of N.laevigatus was inversely proportional to the clay content of the surrounding sediment. Similarly, Nemkov (1962) concluded that nummulites were larger in shallow water calcareous and sandy deposits than in deeper water clayey sediments. Herb and Heckel (1973), in a study of N. fabiani (A-forms), concluded that they were usually larger in marly silts than in other sediments. However, none of these authors indicated whether their studies were based on specimens at a similar ontogenetic stage, and none considered the possible effects of winnowing and sorting.

Variation in size has been found to be greater in 


\begin{tabular}{|c|c|c|c|c|}
\hline \multirow{2}{*}{\multicolumn{2}{|c|}{$\begin{array}{l}\text { MORPHOLOGICAL } \\
\text { CHARACTER }\end{array}$}} & A & B & $\mathrm{c}$ \\
\hline & & DEPENDENT UPON & PRESENCE OR ABSENCE & WEIGHTING \\
\hline \multicolumn{2}{|l|}{ 1. TEST SIZE } & $5,6,7,9,10,11 \& 12$ & & 7 \\
\hline \multicolumn{2}{|l|}{ 2. TEST SHAPE } & $4,5,6,7,10 \& 11$ & & 6 \\
\hline \multicolumn{2}{|c|}{ 3. SEPTAL FILAMENTS/TRACES } & $4,5,6,10(f) \& 12$ & & 5 \\
\hline \multicolumn{2}{|c|}{ 4. PILLARS/GRANULES } & 387 & YES & 2 \\
\hline \multirow[t]{3}{*}{ 5. CHAMBERS } & (a) SHAPE & $2,6, \& 10$ & & 3 \\
\hline & (b) SIZE & $2,6 \& 10$ & & 3 \\
\hline & (c) NUMBER & $2,6 \& 10$ & & 3 \\
\hline \multirow[t]{2}{*}{ 6. SEPTA } & (a) SHAPE & $2,5 \& 10$ & & 3 \\
\hline & (b) NUMBER & $2,5 \& 10$ & & 3 \\
\hline \multicolumn{2}{|c|}{ 7. MARGINAL CORD } & 4 & & 1 \\
\hline \multicolumn{2}{|c|}{ 8. PROLOCULUS SIZE } & & & 0 \\
\hline \multicolumn{2}{|c|}{ 9. PROLOCULUS SHAPE } & & & 0 \\
\hline \multirow[t]{7}{*}{ 10. SPIRE } & (a) REGULAR & $5 \& 6$ & & 2 \\
\hline & (b) IRREGULAR & $5 \& 6$ & & 2 \\
\hline & (c) TIGHT & $1,5 \& 6$ & & 3 \\
\hline & (d) LOOSE & $1.5 \& 6$ & & 3 \\
\hline & (e) TRIPARTITION & $5 \& 6$ & YES & 2 \\
\hline & (f) DOUBLING & $1,2,5,6 \& 7$ & YES & 5 \\
\hline & (g) REVERSALS & $1,2,5,6 \& 7$ & YES & 5 \\
\hline \multicolumn{2}{|c|}{ 11. ALAR PROLONGATIONS } & $2,5 \& 7$ & & 3 \\
\hline \multicolumn{2}{|c|}{ 12. TRABECULAE } & 3 & & 1 \\
\hline
\end{tabular}

Fig.3. Relative taxonomic importance of characters according to their degree of interdependence. Column A lists those characters upon which each character is dependent, for example the alar prolongations (character 11) are dependent on test shape (character 2), Chambers (character 5) and the marginal cord (character 7). Column B lists those characters which can be present or absent. Column $C$ weights the morphological characters on the basis of their degree of interdependence with respect to all other characters. For example test size is dependent on 7 other characters (Column A) and hence has a weighting of 7 whilst proloculus size is not dependent on any of the other morphological characters and thus has a weighting of zero. Theoretically the lower the weighting the more potentially useful the character in species discrimination.

megalospheric than microspheric forms. For example, in $N$. gizehensis A-forms from a single bed in Oman, test diameters varied from $3.67 \mathrm{~mm}$ to $6.41 \mathrm{~mm}$ and thicknesses from $1.6 \mathrm{~mm}$ to $3.75 \mathrm{~mm}$ (Racey, 1988). Such ranges encompass those of a number of species of similar age and test size and is not, therefore, considered to be a generally reliable character for species discrimination, at least not for species of similar age. It is, however, sufficiently variable within the genus to be of value for the discrimination of some species, for example, a small primitive Upper Palaeocene species e.g. $N$. deserti could readily be distinguished from a much larger, more evolved, Middle Eocene speciese.g.N. gizehensis on size alone. Lanterno \& Roveda (1957) examined variation in diameter to thickness ratio in three groups of nummulites; $N$. ramondiformis, $N$. boucheri and N. vascus. They concluded that the diameter to thickness ratio showed distinct clusters for the three B-forms. However, the values for the A-forms showed complete intergradation.

It is concluded that test size is affected by temperature, water depth and substrate. Variation in megalospheric forms is greater than in microspheric forms. Test size is, therefore, not considered a reliable character for species discrimination.

\section{(2) Test Shape}

Reiss et al. (1977) have shown that in Operculina ammonoides and Heterostegina depressa (extant nummulitids) from the Red Sea, involute, thick tests are commonest in shallow waters, and evolute, thin tests in deeper waters. Larsen (1976) noted a similar trend for Recent Amphistegina from the Gulf of Elat, Red Sea. Furthermore, Hallock (1986) observed that test shape in Amphistegina gibbosa and A. lessoni grown in culture was affected by light flux and water motion. She demonstrated that these factors influenced the deposition of secondary lamellae in the test wall, noting that increased light saturation and water motion produced a thicker wall and therefore a thicker test. However, she also noticed that although water motion increased the test thickness (through increased calcification) it retarded the overall growth rate. Slower growth was also observed by Röttger (1976) in Heterostegina depressa under 


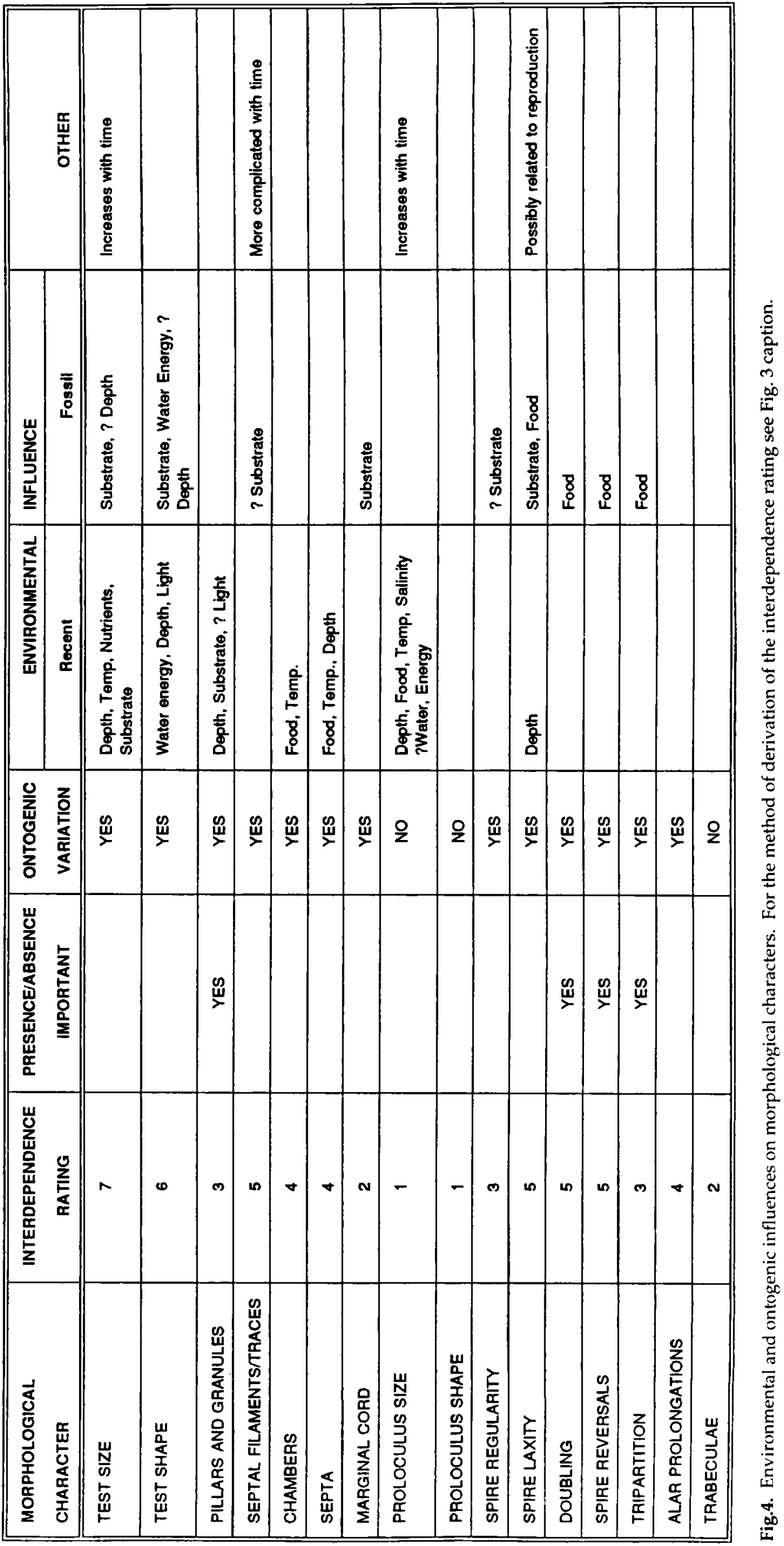


conditions of increased water motion. Hallock \& Hansen (1986) concluded that thin tests represented quiet, low light saturation environments whereas thick tests were indicative of higher energy, higher light saturation, shallower environments. Other studies (Hansen \& Buchardt, 1977; Larsen \& Drooger 1977; Hallock \& Hansen 1979) of Recent symbiontbearing species have also indicated that test morphology changes with habitat depth.

Environmentally controlled variation in test shape has also been reported for fossil species. Flatter nummulites were observed by Veillon \& Vigneux (1960) in calcareous-sandy sediments, while lenticular forms were most commonly found in marly-calcareous strata and globular forms in marly-sandy deposits. However, the definitions of the these sediment types and test shapes were poor. Nemkov (1962) concluded that nummulites in more calcareous deposits were larger and flatter than those found in sandy sediments, a conclusion not in agreement with that of Veillon \& Vigneux (1960). In a study of N.fabiani (A-forms), Herb \& Heckel (1973) recorded a threefold division of test shapes, possibly related to substrate, noting that thin, flat forms occurred in siltstones, thick lenticular forms in limestones and intermediate forms in marly siltstones. In the Gulf of Aqaba, Red Sea, Reiss \& Hottinger (1984) observed that although the extant nummulitids, Operculina ammonoides and Heterostegina depressa, occupy the same depth zone $(20-130 \mathrm{~m})$ they are separated by the characters of their preferred substrate. The former lives on soft sediment between Halophila plants where water energy is low, whereas the latter lives on a firm substrate at the base of corals, on boulders or on coarse coral debris where water energy is higher. Gary \& Healy-Williams (1986), in a study of morphological variability in Recent Bolivina albatrossi from the Gulf of Mexico, noted distinct changes in test form (spindle-shaped to triangular), and related this to dissolved oxygen content.

That environmental factors affect test morphology is evident from the material collected in Oman. The microspheric forms of $N$. gizehensis and N.perforatus develop more rounded peripheries in high energy grainstones, but are thinner and possess more angular peripheries in low energy wackestones. Serra-Kiel \& Reguant (1983) stated that B-forms of N. perforatus have more whorls and become more spherical in higher energy environments and Haynes (1965) commented that shape should be a useful indicator of environments if, in symbiont-bearing taxa, it is controlled by hydrodynamic factors and the metabolic needs of the symbiotic relationship. This possibility is discussed again below. Test shape is not, however, controlled solely by environmental factors since it may also vary with the stage of ontogenetic development. Juvenile Bforms of N. obtusus and N. perforatus form Oman have biconvex tests with angular peripheries, whereas adults have planoconvex to concavo-convex tests with well-rounded peripheries.

It is concluded that test shape is affected by water movement, light intensity, temperature, water depth and substrate. It is not thereforeconsidered a reliable species-diagnostic character.

\section{(3) Ornament}

(a) Septal Filaments/Filament Traces

Little has been published on variation in septal filaments with respect to environmental changes. Herb \& Heckel (1973) in their study of $N$. fabiani A-forms, concluded that forms from silty sediments exhibited a greater degree of reticulation than those from limestones. Septal filaments are known to vary during ontogeny. For example, in $N$. gizehensis they are initially simple and radiate, but in later whorls they become more complex, i.e. meandriform. In N. fichteli they are initially simple, radiating around a single polar pustule, developing later into a complex reticulate network. It is concluded that septal filaments may be affected by substrate (carbonate content) and that they reflect stages of ontogenetic development.

\section{(b) Granules/Pillars}

External characters have often been used for the discrimination of new species and varieties. Some authors, for example Schaub (1963, 1981), have used the arrangement of pillars/ granules to define groups of nummulites. Ornament can, however, vary in strength, position, and number of granules / pillars within a single population, especially among A-forms, though it cannot at present be positively correlated with changes in environment. Freudenthal (1969), in a study of Neogene Heterostegina from Crete, noted that external ornament and test shape could often be correlated with substrate type and were therefore unreliable for the discrimination of species within this genus. He observed that specimens collected from limestones and sandy limestones were thick and had smooth or very lightly granulated surfaces whereas those from sandstones were distinctly granulated. Individuals from argillaceous sediments were the thinnest and most strongly granulated.

Reiss \& Hottinger (1984) noted that the evolute, flat Operculina ammonoides (living below 60m depth in the Gulf of Aqaba) is characterised by single or multiple interseptal "pillars" which reach the shell surface to form "bumps", whereas involute forms from shallower water coral and sand substrates are smooth. They interpreted these pillars as "lenses" for collecting the reduced light at these depths, thus allowing the algal symbionts to continue photosynthesising. However, pillars in species which live in shallower water could equally well be simple strengthening devices for adaptation to higher energy environments. Moreover, pillars and granules may change in strength and number during ontogeny. For example, in the Aform of N.obtusus, juveniles have well-developed pustules whereas adults are non-granulate (see Samanta 1981a). Reiss (1963) stated that the continuity of inflational pillars over chamber sutures, often emphasised by various authors, is due simply to lamellar superposition and represent no special feature. He further notes that the same is true of inflational pillars which are "weaker" on ontogenetically later chambers, an observation made previously by others (e.g.Pokorny, 1958) and believed to represent a gerontic character. Such pillars may have acted as light-collecting lenses for juvenile forms living in deeper water, which later migrated into shallower water where the light flux was sufficient to sustain algal symbiosis without the need for "lenses" (Hottinger, 1977b). There is, however, no direct evidence for such migrations nor is there any evidence from the pillar composition and structure to suggest that such pillars could function as lenses. In Nummulites discorbinus, for example, the polar pillar visible on 
the test surface of some juvenile B-forms may be obscured by the later spiral laminae of the adults, in others it is absent altogether. This feature is therefore not always species-diagnostic. Studies of ornament in other genera have also revealed changes associated with environment. For example, Lutze (1964), in a study of Recent Bolivina argentea, noted that the length of the basal spine, length of the costae and the width/ length ratio of the test increased gradually from basin to slope environments. He concluded that no new species should be erected unless material from more than one locality ("environment") was available, and attempts had been made to find transitional forms from different biotopes Gary \& HealyWilliams (1986) noted a gradual reduction in the coarseness of surface sculpture, and an increase in spine density with increasing water depth, for Recent Bolivina subspinescens and Uvigerina peregrina.

It is concluded that pillars/granules are affected by water depth, substrate, light intensity and stage of ontogenetic development. They are therefore not considered to be reliable species-diagnostic characters.

\section{(4) Spire}

Veillon and Vigneux (1960) concluded that nummulites with looser spires (and flatter tests) were commonest in calcareous sands, whereas those with compact spires (and globular tests) are most common in marly sands. Said (1950) suggested that the tightening of the outer whorls to form a tripartite spire in $N$. gizehensis may be a seasonal feature caused by a limited food supply during winter months. This hypothesis was based on the work of Myers (1943) who observed that Recent Pacific larger foraminifera (including Operculina) added lower and longer chambers during seasons of limited food supply, thus forming a tighter spire compared with those added when food was abundant. Hottinger (1977b), in a study of Recent Operculina ammonoides from the Red Sea, observed that involute, thick forms with a narrow growth spiral occupied shallower water than evolute thin forms with a broader growth spiral which tend to occur in deeper water.

Roveda (1970) noted that some species of Nummulites have been erected mainly on the character of the spire. Arni (1967) based several new varieties on the basis of differences in the spiral diagram. Arni observed that the adult coiling curves often formed an elongated " $\mathrm{s}$ ", and interpreted the moderately curved end portion as representing a declining growth rate. The steep middle portion was considered to represent the main phase of shell growth. He (Arni) argued that growth in this middle portion of the test may have been accelerated by the introduction of intercalary whorls, often causing variation in chamber shape and number of chambers per whorl. Arni postulated that agamont multiplication occurred during the growth of this middle portion of the spire when the nummulite was at its "strongest" (suggested by the occurrence of intercalary whorls) the implication being that intercalary whorls allow a rapid increase in size, and in conjunction with the tightness/looseness of coiling may control the size required for reproduction. He suggested that the moderate curvature of the end portion of the spire (declining growth rate) may be due to the loss of protoplasm and nutrients during reproduction. However, Röttger's laboratory experi- ments have shown that once reproduction begins, growth of the individual ceases, and that afterwards "death" occurs. Roveda (1970) has suggested that spiral growth may be controlled by ecological factors, citing Myers' (1943) observations (outlined previously) for Recent Operculina in support of this conclusion. He also suggested that "oversplitting" of Nummulites may be caused by over-emphasis of the speciesdiagnostic value of chamber size, shape and number, all of which affect the form of the spire. Herb \& Heckel (1973), in a study of the megalospheric generation of N. fabianii, concluded that the spire was looser than normal in siltstones, tighter in limestones and normal (i.e. relatively loose) in marly siltstones. However, in the associated B-forms they observed no significant changes in the spire from one lithology to another, though they did record a wide range of variation. In a study of Upper Eocene and Lower Oligocene nummulites from north-west Europe, Drooger et. al (1971) noted that Aforms increased the diameter of the first two whorls and the number of chambers in them with time, and concluded that this permitted the recognition of species within an evolutionary series.

In a recent study of Heterostegina depressa from Ontong, Java, Hughes (1985) showed that the diameter of the first whorl appeared to decrease slightly from $275-450$ microns at $31 \mathrm{~m}$, to 277-400 microns at $38 \mathrm{~m}$ depth. A similar trend has been recorded for the same species in the Gulf of Aqaba, Red Sea (Reiss \& Hottinger, 1984). Schaub $(1962,1963,1966,1981)$ has demonstrated a gradual differentiation of the microspheric spire of Nummulites into three well-defined sections (tripartition) in several lineages, within the Eocene. He considers this to be one of the most important evolutionary trends within Nummulites, and concludes that the middle portion of the spire shows features characteristic of the species, whereas the inner part is more conservative and shows ancestral characters of value for determining phylogeny. He also observes that the outer portion of the spire increases in width, at the expense of the middle part, during evolution, and attains its maximum in the youngest representative of the lineage. This phenomenon has been observed in B-forms of the N. perforatus and N. gizehensis lineages (Racey, 1988) in Oman. Associated A-forms often show a wider range of spiral variation (Racey, 1988). Hottinger (1977b) commented that intraspecific variation in nummulitid growth is greatest in the outermost whorls.

It is concluded that the spire is affected by substrate and food supply, though such affects have been demonstrated only for microspheric forms. Test thickening through the production of many closely appressed whorls, (seen in Bforms of the $N$. perforatus group from Oman (Racey, 1988) and Spain (Serra-Kiel \& Reguant, 1984), may be related to increased water energy. Abnormalities in the spire (possibly caused by environmental influences) are common and can therefore be eliminated as species-diagnostic. The character of the spire (especially in the early and middle whorls) is usually constant and is considered to be a feature of diagnostic importance.

\section{(5) Septa and Chambers}

Myers(1943), in his study of Recent Operculina from the Pacific and Elphidium crispum from the English Channel, noted that 
short, narrow chambers were added during periods of limited food supply. Bradshaw (1957), whilstexperimenting on growth rates in the extant smaller benthic foraminifer, Streblus beccarii tepida, observed that specimens living at higher temperatures $\left(>30^{\circ} \mathrm{C}\right)$ tended to add smaller chambers than those kept at lower temperatures and to produce misshapen tests with chambers of different sizes. He noticed that reproduction in specimens kept under unfavourable conditions produced larger individuals with a greater number of chambers than those which reproduced under favourable conditions. However, his specimens were collected initially from temperate waters around the U.K. The behaviour of such a temperate water species when kept at high temperature may not be a guide to the behaviour of warm-water species normally adapted to temperatures of $25-30^{\circ} \mathrm{C}$. Gary \& Healy-Williams (1986) noted changes in chamber shape in Recent Uvigerina peregrina and Bolivia subspinescens which showed a strong correlation with the dissolved oxygen depth profile. They also observed a linear reduction in chamber lobation in Bolivina albatrossi with increasing water depth. In a study of Heterostegina depressa from the Gulf of Aqaba, Red Sea, Fermont (1977) showed that the average number of operculine chambers is inversely proportional to depth (14-15 at $28 \mathrm{~m}, 12-13$ at $38 \mathrm{~m}$ and $10-11$ at $68 \mathrm{~m}$ ). Specimens grown in laboratory cultures tended to have 10-20 operculine chambers. In the Oman material, chamber shape and size were found to be relatively constant and although variation was seen, e.g. in N. perforatus, this tended to occur at specific points in the spire and could often be related to ontogeny. For example, in B-forms of $N$. beneharnensis the initial chambers are isometric, representing the shape seen in adult forms of the ancestral nummulite, but becoming two to three times longer than high in the outer whorls. Variation in chamber shape and size often occurs in the middle part of the spire where it is related, especially in the larger species, to the introduction of intercalary whorls, e.g. $N$. gizehensis and $N$. perforatus.

It is concluded that septa and chambers are affected by food availability and temperature. They are, however, reliable taxonomic features, variations from the norm (usually associated with abnormalities of the spire) being easily recognised.

\section{(6) Proloculus}

Although often regarded as an essential character for species discrimination, variation in proloculus size in single assemblages has rarely been studied. Khan \& Drooger (1970 in a study of various nummulites A-forms only) from the Lower Eocene of Gan, northern Pyrenees, noted that the diameters given by Schaub (1966) did not truly reflect the range of variation. They concluded that either many unnamed species were present or that proloculus size was variable. Later work on Upper Eocene to Lower Oligocene radiate nummulites from northwest Europe led Drooger et al. (1971) to conclude that megalosphere size was highly variable (30250 microns). Since an increase in megalosphere size with time is considered to be an important evolutionary trend, such a wide range of values may be thought to be surprising; indeed $-N$. fraasi had already attained megalosphere diameters of 100120 microns by the Late Palaeocene. However, N. minutus, a new Middle Eocene species from Oman (Racey, 1988; 1992) has a far smaller proloculus (0.05-0.07) than any previously recorded, i.e. approximately half the size of any published species description. Adams (pers. comm.) has observed a new species of Nummulites with similar proloculus dimensions to N. minutus from an Early Palaeogene sequence in India.

Studies of the proloculus size in $N$. gizehensis (A-forms) from a single Oman sample show a marked size variation (0.66$1.25 \mathrm{~mm}$ ), a phenomenon also noted by Schaub (1981) in an Egyptian population of the same species. Mean values in successive assemblages do, however, show a general increase in size with time, as noted by Drooger et al. (1971) and inferred by Schaub (1981). Drooger et al. (1971) showed that the diameter of the megalosphere was independent of the diameter of the microspheric form. Serra-Keil \& Reguant (1984) concluded that megalosphere size does not vary significantly between populations of the same species from different lithologies, a conclusion partially supported by studies of species from Oman. However, in the Oman material, megalosphere size was found to be fairly variable in some populations and more uniform in others, irrespective of lithology.

Studies of the Recent nummulitid Operculina ammonoides from the Red Sea (Reiss \& Hottinger, 1984) have shown a wide variation in megalosphere size (25-125 microns), and these authors have concluded that the frequency distribution of megalosphere diameter from all depths is bimodal for evolute and unimodal for involute forms. Hughes (1985), in a study of Recent Heterostegina depressa from Ontong, Java, noted proloculus diameters of 37-75 microns at $31 \mathrm{~m}$ depth and 30-75 microns at $38 \mathrm{~m}$ depth. However, specimens of the same species from the Red Sea have far larger proloculi at similar depths, 79.9 - 169.9 microns at $28 \mathrm{~m}$ depth and 79.9-199.9 microns at $68 \mathrm{~m}$ depth. In a study of Recent Elphidium crispum from the English Channel, Myers (1943) reported that the diameter of the megalosphere from tidal pools varied from 28 73 mircons. Reiss \& Hottinger (1984) have suggested that variations in megalosphere size reflect different initial volumes of protoplasm in juveniles and that this depends on the ratio of the total volume of protoplasm in the parent shell to the number of offspring produced during asexual reproduction. They concluded that the final volume of the protoplasmic mass in the parent generation may be related to the rate of food uptake which, in turn, is dependent on food production and population density (=food availability) and to metabolic rates. Nigam and Rao (1987) have shown that in Cavarotalia annectens from the west coast of India, proloculus size is inversely proportional to temperature (range studied $=27.5$ $29.25^{\circ} \mathrm{C}$ ) and to salinity (range studied $=37.7-36$ p.p.t.). Fermont (1977) noted a tendency towards increased proloculus size. with depth in Recent Operculina ammonoides from the Red Sea, and also in the Eocene Discocyclina varians group from Ein Advat, Israel; a similar depth related morphocline has been suggested for Miogypsina species (Drooger and Raju, 1973).

Hallock (1985) has suggested a possible mechanism for variation in proloculus size based upon dependence on algal symbionts. She argued that if juveniles receive more protoplasm and symbionts from the parent, they will remain 
small for only a short period, thus increasing their chances of survival. However, she does not explain why species with small proluculi do not become extinct. Water motion and light decrease with depth; and although water motion is highly variable (changing daily, seasonally etc.) light levels are relatively constant and are therefore predictable, providing that water clarity does not change. She further argued that relatively higher fecundity would produce young with a small proloculus size, thus increasing their chances of survival under highly variable conditions. The production of young with larger embryons would be more likely in stable, low-light conditions. However, Röttger et al. (1987) have proposed an alternative hypothesis based on observations of Recent Heterostegina depressa from Hawaii. Their laboratory observations suggest that two megalospheric forms are distinguishable; one reproducing asexually and the other sexually. They noted that the asexually reproducing form was reproductively isolated from that reproducing sexually and that it therefore constituted a separate apogamic species. The asexually reproducing form was observed to be predominant in shallow water and to decrease in numbers with increasing depth. The sexually reproducing form increased in numbers with depth. This mixture of two megalospheric types could explain the depth-related cline in mean proloculus size noted by Fermont (1977).

Zohary et al. (1980) noted that asexual reproduction cycles for Recent shallow-dwelling Amphisorus and Sorites were synchronous and closely linked with the seasonal cycle. They observed that a population of Amphisorus hemprichii would consist one year of large numbers of megalospheric individuals with comparatively small proloculi and few microspheric forms; the following year the population would comprise only megalospheric forms with large proloculi. As there was no evidence for the migration of microspheric forms out of the system, Leutenegger (1977) suggested that this cycle should be interpreted as being paratrimorphic and co-ordinated with the seasonal cycle over two successive years. If the co-ordination with the seasonally cycle becomes weaker or lost in deeper water (a conclusion supported by Leutenegger's (1977) in-situ observations) then the mixture of megalospheric schizonts and gamonts in a population will change. Consequently changes in proloculus size observed along the depth gradient (Fermont, 1977) may reflect changes in the co-ordination of reproduction cycles with the seasonal cycle. Such a model can however, only be tested by sampling populations over a long time interval, using techniques which avoid the effects of mixing by bioturbation and take into account the patchy distribution of living populations. However, in fossil larger foraminifera it is not possible to find evidence of depthrelated intraspecific morphoclines attributable to different types of reproduction, as postulated above.

It is concluded that proloculus size can be affected by temperature, water depth and food supply. Variation is marked and this character is therefore considered to be unreliable, when used in isolation, for species differentiation.

\section{(7) Marginal Cord}

Few data are available concerning the relationship (if any) between marginal cord development and environmental fac- tors. Herb \& Heckel (1973), in a study of N. fabiani (B-forms), concluded that individuals from carbonate-rich environments had relatively thick marginal cords. Serra-Keil \& Reguant (1984) correlated marginal cord development in N. perforatus with changes in lithology. However, other nummulitids such as $R$. nuttalli and $O$. canalifera have thick marginal cords, yet occur in limestones with perfectly ordinary species of Nummulites in Oman. Marginal cord development cannot, therefore, be easily correlated with carbonate content.

\section{SUMMARY}

All morphological characters, save proloculus size and shape, can vary during the course of ontogeny. Such changes are often well-documented (Schaub, 1981) and should not pose major problems for species discrimination. Environmental influences on morphological characters appear, however, to be complex, while genetic controls are insufficiently known (save for variation in proloculus size) to be considered further here, although they are undoubtably important. Although test size, test shape, ornament and proloculus size show marked intraspecific variation they help to identify the groups to which species belong.

From the above conclusions it is evident that morphological

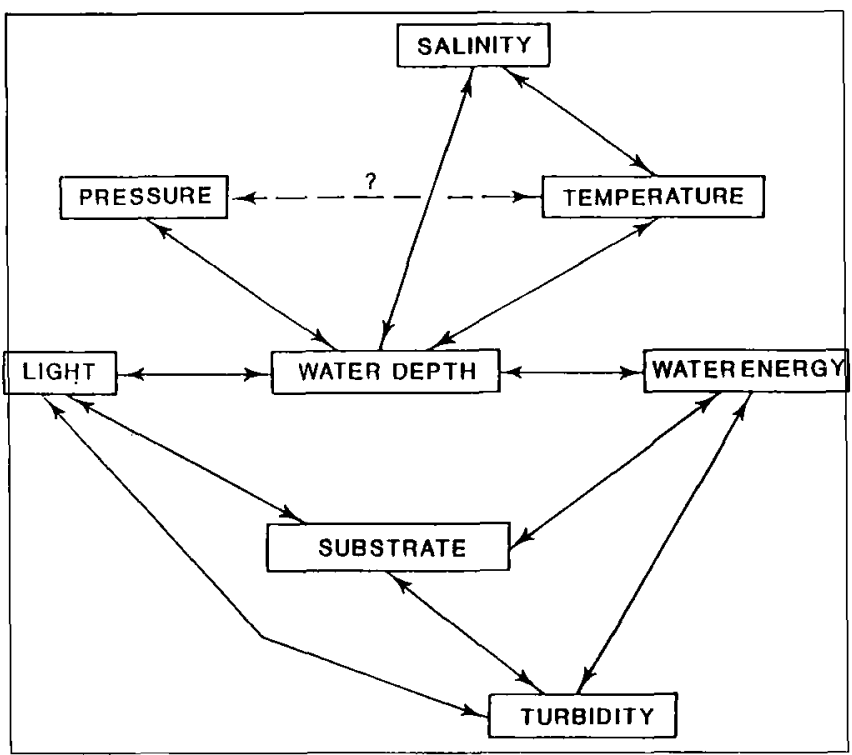

Fig. 5. Interaction of environmental influences

characters are affected to varying degrees by environmental factors. The main problem for the palaeontologist is, however, to assess the relative effects of the various environmental factors on different morphological characters, i.e. in quantifying changes in morphology and determining which environmental influences are most important. Such assessments are difficult because of the interactions between the environmental controls outlined in Fig. 5. Thus, for example, if we conclude that substrate affects a certain morphological character, then we must also consider factors such as water depth, water energy, light intensity and water turbidity which all affect the substrate type. 
Having discussed how morphological characters may be affected by environmental and ontogenic factors (summarised in Fig. 3\& 4) - they are reweighted in order of importance below :-

(a) Shape and form of the septa and chambers

(b) Form of the spire (including presence/absences of doubling, tripartition and or reversals in coiling direction).

(c) Thickness of the marginal cord (including the spiral sheet).

(d) Proloculus size in the megalospheric generation.

(e) Test size and shape.

(f) Septal filaments/filament traces.

(g) Presence/absence and position of pillars/granules.

\section{ACKNOWLEDGEMENTS}

Dr. C.G. Adams (British Museum) (Natural History, London), is thanked for his support and encouragement. Dr. J. E. Whittaker, British Museum (Natural History), London and Prof. J.R. Haynes, University College of Wales (Aberystwyth) provided useful comments on the manuscript. This work was completed while the author was in receipt of a NERC/CASE award to study at the British Museum (Natural History). Hilary Hatch (Geochem Group Limited) is thanked for her technical support.

\section{Manuscript received May 1992}

Manuscript acepted July 1992

\section{REFERENCES}

Arni, P. 1967. A comprehensive graph of essential diagnostics of the Nummulites. Micropaleontology 13, 41 - 54.

Barnett, R.S. 1969. An application of numerical taxonomy to the classification of the Nummulitidae (Foraminiferida). J. Paleont., Vol. 48, 1249-1263.

Bieda, F. 1963. Larger foraminifers of the Tatra Eocene. Pr. Inst. geol., 37, 1 - 215.

Blondeau, A. 1972. Les Nummulites. Paris, Vuibert, p. 1 - 38

Bradshaw, J. 1957. Laboratory studies on the rate of growth of the Foraminifer "Streblus beccarii (Linnaeus) var tepida (Cushman)". J. Paleont., 31, 1138-1147.

Carpenter, W.B. 1850. On the microscopic structure of Nummulina, Orbitolites and Orbitoides. QJl.geol. Soc. Lond., 6 (for 1849), p. 21 - 38.

Drooger, C.W., Marks, P.\& Papp, A. 1971. Smaller radiate nummulites of North western Europe. Utrecht micropaleont. Bull., 5, p. 1 - 137, 5 pls.

Drooger, C.W. \& Raju, D.S.N. 1973. Protoconch diameter in the Miogypsinidae. Proc. K. ned. Akad. Wet., \#76 (3), p. 206-216.

Fermont, W.J.J. 1977. Biometrical investigation of the genus Operculina in recent sediments of the Gulf of Elat. Utrecht micropaleontol. Bull., 15, 171-204.

Freudenthal, T. 1969. Stratigraphy of Neogene deposits in the Khania Province, Crete with special reference to the family Planorbulinidae and the genus Heterostegina. Utrecht micropaleont. Bull., 1, 1- 208.

Gary, A.C. \& Healy-Williams, N. 1986. Environmental control on morpholigic variability of Uverigerina peregrina, Bolivina albatrossi and Bolivina subspinescens. Benthos '86: 3rd lnt. Symp. Benthic Foraminifera (Geneva) Abstract.

Golev, B.T. 1961. Sur le genre Operculiniodes Hanzawa. Vop. Mikrop. paleont. 5, 112 - 120.

Hallock, P. 1985. Why are larger foraminifera large? Paleobiol, 11, p. 195 - 208
Hallock, P. \& Hansen, H.J. 1979. Depth adaptation in Amphistegina : change in lamellar thickness. Bull. geol. Soc. Denm., 27, 99 - 104.

Hallock, P., Forward, L. B. \& Hansen H.J. 1986. Influence of environment on the test shape of Amphistegina. J. foramin. Res., 16 (3) 224-231.

Hallock, P. \& Glenn, C. 1986. Larger forminifera : A tool for palaeoenvironmental analysis of Cenozoic carbonate depositional facies: Palaios, 1, 55-64.

Hansen, H.J. \& Buchardt, B. 1977. Depth-distribution of Amphistegina in the Gulf of Elat, Israel. Utrecht micropaleont. Bull., 15, 205 - 224.

Haynes, J.R. 1965. Symbiosis, wall structure and habitat in larger foraminifera. Contr. Cushman. Fdn. foram. Res., 16, $40-43$.

Herb, R. \& Heckel, H. 1973. Biostratigraphy, variability and facies relations of some Upper Eocene nummulites from Northern Italy. Eclog. geol. Helv., 66, 419 - 445.

Hottinger, L. 1977a. Foraminfères operculiniformes. Mém. Mus. natn. Hist. nat. Paris), (C) Sci. de la terre, 40, 1 - 159.

Hottinger, L. 1977b. Distribution of larger Peneroplidae, Borelis and Nummulitadae in the Gulf of Elat, Red Sea. Utrecht micropaleont. Bull., 16, 35-110.

Hottinger, L. 1981. The resolution power of the biostratigraphic clock based on evolution and its limits. In: Martinelli, J. (ed). Internatl. Symp. Meth. Paleont, Barcelona, pp. 233 - 242.

Hughes, G.W. 1985. Recent foraminifera and selected biometrics of Heterostegina from Ontong Java Atoll, Solomon Islands, southwest Pacific. J. foramin. Res., 15, 13 - 17.

Keller, G. 1983. Palaeoclimatic analyses of Middle Eocene through Oligocene planktic foraminiferal faunas. Palaeogeogr. Palaeoclimat., Palaeoecol., 43, 73 - 94.

Khan, M.A. \& Drooger, C.W. 1971. On variation in Nummulites assemblages. Proc. k. ned. Akad. Wet. (B), 74, 97 - 121.

Lanterno, E. \& Roveda, V. 1957. Sur les couples de Nummulites incrassatus (B) - N. ramondiformis (A) et N. vascus (B) -N. boucheri(A). Arch. Sci. Geneve, $14137-170$, pl.

Larsen, A.R. 1976. Studies of Recent Amphistegina. Taxonomy and some ecological aspects. Israel. J. Earth Sci., 25, 1 - 26.

Larsen, A.R. \& Drooger, C.W. 1977. Relative thickness of the test in the Amphistegina species of the Gulf of Elat. Utrecht micropaleontol. Bull., 15, 225 - 239.

Lee, J.J., McEnnery, M.E. \& Kahn, E.G. 1979. Symbiosis and the evolution of larger foraminifer. Micropaleontology, 25118 - 140.

Leutenegger, S. 1977. Reproduction cycles of larger foraminifera and depth distributions of generations. Utrecht micropaleont. Bull., 15, 27 -34 .

Lutze, G.F., 1964. Statistical investigations on the variability of Bolivina argentea (Cushman). Contr. Cushman Fdn.foramin. Res., 15, p. $105-116$.

Myers, E.H. 1943. Ecologic relationships of larger foraminifera. Rep. Comm. mar. Ecol. Paleont. Wash. 26-33.

Nemkov, G.I. 1962. Remarks on the palaeoecology of Nummulites. Vop. Mikropaleont. 6, 64 - 72.

Nigam, R. \& RAO, S. 1987. Proloculus size variation in Recent benthic foraminifera: implications for palaeoclimatic studies. Estuar. cst. Shelf Sci., $24649-655$.

Papp, A. \& Küpper, K. 1954. The genus Heterostegina in the Upper Tertiary of Europe. Contr. Cushman Fdn. foramin. Res., 5, 108 - 127.

Pomerol, C. 1961. Les Nummulites de l'Eocéne d'Angleterre; conditions de dépot et problemes stratigraphiques. Cah. géol., No.64-65, $653-662$.

Pokorny, V. 1958. Grundzäge der Zoologischen Mikropaläontologie, Vol. 1. Berlin, VEB Deutscher Verlag der Wissenschaften, 582 pp.

Racey, A. 1988. Nummulitid biostratigraphy and Palaeogene palaeonvironments, Sultanate of Oman. PhD thesis, University of London, 510 pp. [Unpublished]. 
Racey, A. 1992. New nummulite (foraminifera) species from the Eocene of Northern Oman. J. Micropalaeontol., 11 (2), 189-195.

Reiss, Z. 1963. Reclassification of perforate foraminifera. Bull. Geol. Surv. Israel, 351 - 111.

Reiss, Z., Leutenegger, S., Hottinger, L., Hansen, H.J., Fermont, W.J.J., Meulenkamp, J.E., Thomas, E., Buchardt, B., Larsen, A.R. \& Drooger, C.W. 1977. Depth-relations of Recent larger foraminifera in the Gulf of Aqaba-Elat. Utrecht micropaleont. Bull., 15, 1 - 244.

Reiss, Z. \& Hottinger, L. 1984. The Gulf of Aqaba. Ecological Micropalaeontology. Berlin, Springer Verlag, p. 1 - 354 pp.

Ross, C.A. 1972. Biology and ecology of Marginopora vertebralis (Foraminiferida), Great Barrier Reef. J. Protozool., 19, 181 - 192.

Ross, C.A. 1974. Evolutionary and ecological significance of large calcareous Foraminiferida (Protozoa), Great Barrier Reef. In: Proc. 2nd Int. Symp. Coral Reefs, The Great Barrier Reef Committee, Brisbane, Qld., 327 - 333.

Röttger, R. 1976. Ecologic observations of Heterostegina depressa (Foraminifera : Nummulitidae) in the laboratory and in its natural habitat. Marit. Sediments Spec. Publs., 1, 75 - 80.

Röttger, R. 1984. Die Grossforaminifere Heterostegina depressa-Vieltung der mikrosphärischen und der megalosphärischen Generation. Film C1506 des IWF, Göttingen 1983. Publikationen zu wissenschaftlichen Filmen, Sektion Biologie, Serie 16, No. 28/C 1506.

Röttger R. 1987. Heterostegina apogama a new Holocene nummulitid (Protozoa, Foraminiferida) from Hawaii. J. foramin. Res., 17 187-189.

Roveda, V. 1970. Revision of the Nummulites (foraminiferida) of the N. fabianii-fichteli group. Riv. ital. Paleont., 76235 - 324.

Said, R. 1950. Nummulites gizehensis as a possible indicator of Eocene climate. Contr. Cushman. Fdn. foramin. Res., 1, 30 - 31.

Samanta, B.K. 1981a. Two stratigraphically important nummulites from the Middle Eocene of India and Europe. Palaeontology 24, 803 $-826$.

Samanta, B.K. 1981b. Morphology and stratigraphic distribution of Nummulites maculatus Nuttall with observations on the extinction of large nummulites near the Middle/Upper Eocene boundary. $Q$. Jl. geol. Min. metall. Soc. India, 53, 14 - 35.
Schaub, H. 1962. Über einige stratigraphisch Wichtige NummulitenArten. Eclog. geol. Helv., 55, 529 - 551.

Schaub, H. 1963. Über einige Entwicklungsreihen von Nummulites und Assilina und ihre stratigraphische Bedeutung. In: Evolutionary Trends in Foraminifera, von Königswald G.H.R. (eds.) et al. Elsevier, Amsterdam, pp. 282-297.

Schaub, H. 1966. Uber die Grossforaminiferen im Untereocaen von Campo (Ober-Aragonien). Eclog. geol. Helv., 59, 335 - 377.

Schaub, H. 1981. Nummulites et Assilines de la Tethys paleogene, Taxinomie, phylogenese et biostratigraphie. Abh. Schweiz Pal_ont. Geo., 104-106 1-236.

Serra-Kiel, J. \& Reguant, S. 1984. Palaeoecological conditions and morphological variation in monospecific banks of nummulites - an example. In : Oertli, H.J. (ed.) Benthos '83, 2nd Int. Symp. Benthic Foraminifera (Pau). Pau \& Bordeaux, Elf \& Aquitaine, Esso REP, Total CFP, pp. 557-563.

Shackleton, N.J. \& Kennet, J.P. 1975. Paleotemperature history of the Cenozoic and the initiation of Antarctic glaciation: oxygen and carbon isotope analyses in DSDP sites 277,279 and 281. Inititial Rep. deep Sea Drilling Proj., 29743 - 755.

Tan Sin Hok, 1932. On the genus Cycloclypeus Carpenter and an appendix on the heterostegines of Tjimanggoe, S. Bantam, Java. Wt. Meded. Dienst Mijnb. Ned. Oost-Indie, 19, 3-141.

Veillon, M. \& Vigneaux, M. 1960. Raport entre la morphologie génènerale des Nummulites et le lithofaciés. C.r. somm. Séanc. Soc. géol. Fr., 1960, 243 - 244.

Vlerk, I.M. van der \& Bannink, D.D. 1969. Biometrical investigations on Operculina. Proc. K. ned. Akad. Wet., (B) 72169 - 174.

Whittaker, J.E. \& Hodgkinson, R.L. 1979. Foraminifera of the Togopi Formation, eastern Sabah, Malaysia. Bull. Br.Mus.nat. Hist. (Geol.), 31, 1 - 120.

Zohary, T., Reiss, Z. \& Hottinger, L. 1980. Population dynamics of Amphisorous hemprichii (Foraminifera) in the Gulf of Elat (Aqaba), Red Sea. Eclog. geol. Helv., 72, 1071 - 1094. 